\title{
16 \\ Using Content-Specific Lyrics to Familiar Tunes in a Large Lecture Setting
}

\author{
Derek T. McLachlin \\ University of Western Ontario
}

Music can be used in lectures to increase student engagement and help students retain information. In this paper, I describe my use of biochemistry-related lyrics written to the tune of the theme to the television show, The Flintstones, in a large class setting (400-800 students). To determine student perceptions, the class was surveyed several weeks after the song was used. Students reported a high level of engagement and enjoyment during the song. Many students found the song to be a helpful study tool. To guide future song selection, the students were also asked to indicate their familiarity with 30 popular songs from the past 50+ years. The songs that were least familiar to the students were all released before 1980, but some older songs were well known. The results support the use of content-specific lyrics set to familiar tunes as an educational tool, and provides information about specific songs that would or would not be suitable for this purpose.

L

earning a song requires storage of melodic and Dexic and text are processed in different pats of music and text are processed in different parts of the brain (Samson \& Zatorre, 1991; Besson, Faïta, Peretz, Bonnel, \& Requin, 1998), song tunes and lyrics are associated with each other in memory, such that the recall of one aids in the recall of the other (Calvert \& Tart, 1993; Ginsborg \& Sloboda, 2007). Teachers can take advantage of this association to help students learn concepts related to their field of study by presenting information in the form of a song.

It is easier to learn unfamiliar words when they are set to a familiar tune rather than an unfamiliar tune (Wolfe \& Hom, 1993; Claussen \& Thaut, 1997). Therefore, it is better to associate information to be learned with a tune that is already a part of long-term memory. For this reason, teachers have written content-specific lyrics to popular songs (Dickson \& Grant, 2003; Gilbert, 2006) to associate new information with melodies already present in the student's long-term memory. The intent of this practice is to help students retain information in a fun and engaging way.

A notable author of such songs in my field (biochemistry) is Dr. Kevin Ahern of the Depart- 
ment of Biochemistry and Biophysics at Oregon State University (Ahern, n.d.). Examples of songs he has written are $B-D N A$ (to the tune of $Y M C A$ ), The Sound of Glucose (to the tune of A Few of My Favourite Things), and The Cell's Lament (to the tune of Yesterday).

In my introductory, second-year biochemistry course, I have used The Histone Song (Gilbert, 2006) in a lecture on DNA packaging. The lyrics of this song, written by Scott F. Gilbert of the Department of Biology at Swarthmore College, describe the packaging of DNA into nucleosomes. The song is sung to the tune of the theme to the television show The Flintstones. I project the words onto a screen, and invite the students to sing the song with me, a cappella. I also ask the students to clap in time to keep the beat. Student-captured video of the use of the song in my class can be viewed on Youtube (Meet the histones!, 2008). After class, the lyrics to the song are made available to the students via the internet. This is a popular component of the lecture, based on comments received from students in person and on anonymous course evaluations. To better evaluate the effectiveness of this song as a learning tool, I was interested in obtaining a broader sample of student opinion.

In addition, in 2007 it struck me that The Flintstones originally aired in the early 1960 s, but the vast majority of my students were born in the late 1980s. I was therefore concerned that many students would be unfamiliar with the tune to the show's theme song, making The Histone Song less effective as a teaching tool. Most of Dr. Ahern's songs are also based on songs popular before 1980, from movies released before 1980, or from Christmas songs that may be unfamiliar to students from non-Western backgrounds. With these thoughts in mind, I conducted a survey of the students in my class, first, to gain information about their classroom experience of The Histone Song, and second, to determine their overall familiarity with songs popular in North America over the last 50 years. A 41-item survey was distributed during the last class of the semester in December 2007. The survey was completed anonymously and students were clearly told that completion of the survey was optional. A total of 599 surveys were re- turned with at least one question answered, out of a course enrolment of 1192 (50.3\% response rate).

The first part of the survey asked students about the use of The Histone Song in class. Of the students who were in class when the song was sung, engagement in the activity was high: 69\% reported singing along and $81 \%$ reported clapping along. Seventy-five percent of students reported enjoying that part of the lecture 'very much,' with $20 \%$ saying they enjoyed it 'quite a bit.' Six percent indicated that some aspect of the performance made them uncomfortable, but $77 \%$ of these students still enjoyed the song 'very much' or 'quite a bit,' and the proportion who sang or clapped along was similar to the students who did not report discomfort.

Enjoyment of the song continued outside of lecture. Fifty-five percent reported singing the song, either in their heads or out loud, at least once in the five weeks since the lecture. This means that over half of the class had thought to some degree about DNA packaging before the survey, which was conducted about two weeks before the final exam. Forty-four percent of the students thought that the song would be 'very helpful' or 'quite helpful' as they studied, while $11 \%$ felt the song would be 'not helpful.' Therefore, the song seems to be a helpful study tool for a large proportion of students.

In the second part of the survey, students were presented with the title and recording artist of popular songs from the 1950s to the present, or with a television show theme. They were asked whether they were familiar with any part of the tunes to these songs. The songs that were least familiar to the students tended to be the older songs, but some songs released in the 1960s, 1970s and 1980s were familiar to many students (Table 1). Ninety-six percent of students reported that they were familiar with the theme to The Flintstones before the class in which we sang The Histone Song. The list of songs included several (indicated by asterisks in Table 1) to which Dr. Ahern has written biochemistry-specific lyrics. These songs vary considerably in their familiarity to students.

Features of music that aid in recall of lyrics include not only the melody line itself but also rhythmic elements, stress of certain beats, organization 


\section{Table 1}

Familiarity of Undergraduate Students with Popular Songs from the 1950s to the Present

\begin{tabular}{|c|c|c|c|}
\hline Title & Artist & $\begin{array}{l}\text { Year of release or } \\
\text { original air dates }\end{array}$ & $\begin{array}{l}\text { Percentage of students } \\
\text { reporting familiarity }\end{array}$ \\
\hline *YMCA & The Village People & 1978 & 97.3 \\
\hline The Flintstones theme song & - & $1960-66$ & 96.4 \\
\hline Friends theme song & - & 1994-2004 & 93.6 \\
\hline SexyBack & Justin Timberlake & 2006 & 93.1 \\
\hline Girlfriend & Avril Lavigne & 2007 & 88.1 \\
\hline Girls just want to have fun & Cyndi Lauper & 1983 & 87.4 \\
\hline Wannabe & The Spice Girls & 1996 & 83.1 \\
\hline A moment like this & Kelly Clarkson & 2002 & 82.7 \\
\hline Yeah & Usher & 2004 & 81.4 \\
\hline Respect & Aretha Franklin & 1967 & 80.5 \\
\hline Hotel California & The Eagles & 1976 & 80.2 \\
\hline$A B C$ & The Jackson Five & 1970 & 80.2 \\
\hline *Yellow submarine & The Beatles & 1969 & 78.5 \\
\hline Billie Jean & Michael Jackson & 1983 & 78.3 \\
\hline All star & Smash Mouth & 1999 & 77.4 \\
\hline *American pie & Don McLean & 1971 & 74.0 \\
\hline *Yesterday & The Beatles & 1965 & 71.7 \\
\hline Like a prayer & Madonna & 1989 & 67.4 \\
\hline All I wanna do & Sheryl Crow & 1994 & 62.6 \\
\hline $\begin{array}{l}\text { I still haven't found what I'm } \\
\text { looking for }\end{array}$ & U2 & 1987 & 59.3 \\
\hline Smells like teen spirit & Nirvana & 1991 & 58.5 \\
\hline Cheers theme song & - & 1982-93 & 53.3 \\
\hline *Danny boy & Traditional Irish song & - & 39.1 \\
\hline Mr. Sandman & The Chordettes & 1954 & 34.4 \\
\hline Gilligan's Island theme song & - & $1964-67$ & 33.3 \\
\hline *Blowin' in the wind & Bob Dylan & 1963 & 31.4 \\
\hline Put your head on my shoulder & Paul Anka & 1959 & 24.4 \\
\hline $\begin{array}{l}{ }^{*} \text { Thank God I'm a country } \\
\text { boy }\end{array}$ & John Denver & 1974 & 23.2 \\
\hline $\mathrm{M}^{*} \mathrm{~A}^{*} \mathrm{~S}^{*} \mathrm{H}$ theme song & - & $1972-83$ & 17.1 \\
\hline Blueberry Hill & Fats Domino & 1956 & 6.3 \\
\hline Chances are & Johnny Mathis & 1957 & 5.4 \\
\hline
\end{tabular}

* Songs to which Dr. Kevin Ahern of the University of Oregon has set biochemistry-related lyrics. 
into phrases of defined length, sequence cues, and repetition or regularity of elements (Gingold \& Abravanel, 1987; Hyman \& Rubin, 1990). Music that is ill-suited to the lyrics in terms of these features can interfere with learning and recall of lyrics (Gingold \& Abravanel, 1987).

Given the above, instructors seeking to write their own words to popular tunes should strive to select songs with which the students are likely to be familiar; and appropriately match the lyrics to the melody.

A question of potential concern is whether the use of popular songs in this manner infringes copyright. Section 29.5 of the Copyright Act of Canada (1985) states:

It is not an infringement of copyright for an educational institution or a person acting under its authority to do the following acts if they are done on the premises of an educational institution for educational or training purposes and not for profit, before an audience consisting primarily of students of the educational institution, instructors acting under the authority of the educational institution or any person who is directly responsible for setting a curriculum for the educational institution:

(a) the live performance in public, primarily by students of the educational institution, of a work...

A large number of students sing along with me, and thus I would argue that the performance is primarily by students, and therefore not an infringement of copyright. However, instructors may wish to contact the copyright owners of songs they want to use in class, to obtain explicit permission to use the songs in this way.

The results of my survey show that my second-year university students find The Histone Song to be an enjoyable part of lecture as well as a useful study aid. Well-written songs of this type can enliven a lecture and provide students with an entertaining way to review material.

\section{References}

Ahern, K. (n.d.). Kevin Ahern's wildly popular metabolic melodies. Retrieved September 24, 2008, from http://www.davincipress.com/ metabmelodies.html

Besson, M., Faïta, F., Peretz, I., Bonnel, A. M., \& Requin, J. (1998). Singing in the brain: Independence of lyrics and tunes. Psychological Science, 9, 494-498.

Calvert, S. L. \& Tart, M. (1993). Song versus verbal forms for very-long-term, long-term, and short-term verbatim recall. Journal of Applied Developmental Psychology, 14, 245-260.

Claussen, D. W. \& Thaut, M. H. (1997). Music as a mnemonic device for children with learning disabilities. Canadian Journal of Music Therapy, 5, 55-66.

Copyright Act of Canada. (1985). Retrieved April 3, 2009, from http://laws.justice.gc.ca/en/C42/index.html

Dickson, D. \& Grant, L. (2003). Physics karaoke: Why not? Physics Education, 38, 320-323.

Gilbert, S.F. (2006). Song: The histone song (to the tune of 'The Flintstones'). Biochemistry and Molecular Biology Education, 34, 111.

Gingold, H. \& Abravanel, E. (1987). Music as a mnemonic: The effects of good- and badmusic settings on verbatim recall of short passages by young children. Psychomusicology, 7, 25-39.

Ginsborg, J. \& Sloboda, J.A. (2007). Singers' recall for the words and melody of a new, unaccompanied song. Psychology of Music, 35, 421-440.

Hyman, I. E. \& Rubin, D.C. (1990). Memorabeatlia: 
A naturalistic study of long-term memory. Memory \& Cognition, 18, 205-214

Meet the histones! (2008). Retrieved April 3, 2009, from http://www.youtube.com/ watch?v=tbB8n9J6vfI

Samson, S. \& Zatorre, R. J. (1991). Recognition memory for text and melody of songs after unilateral temporal lob lesion: Evidence for dual encoding. Journal of Experimental Psychology: Learning, Memory and Cognition, 17, 793-804.

Wolfe, D. E. \& Hom, C. (1993). Use of melodies as structural prompts for learning and retention of sequential verbal information by preschool students. Journal of Music Therapy, 30, 100118.

\section{Biography}

Derek T. McLachlin is an Assistant Professor in the Department of Biochemistry at the University of Western Ontario in London, Ontario. He has conducted biochemical research in the areas of protein chemistry and the analysis of protein phosphorylation by mass spectrometry. His interests focus on the scholarship of teaching and learning, particularly in the area of student engagement. 